\title{
Chemical treatment of teff straw by sodium hydroxide, phosphoric acid and zinc chloride: adsorptive removal of chromium
}

\author{
A. B. Wassie $^{1}$ - V. C. Srivastava ${ }^{1}$
}

Received: 12 February 2016/Revised: 16 June 2016/Accepted: 23 July 2016/Published online: 10 August 2016

(C) Islamic Azad University (IAU) 2016

\begin{abstract}
In this study, teff (Eragrostis tef) straw has been chemically treated and tested as an adsorbent for $\mathrm{Cr}(\mathrm{VI})$ removal. Chemically treatment of teff straw was done by $\mathrm{NaOH}, \mathrm{H}_{3} \mathrm{PO}_{4}$ and $\mathrm{ZnCl}_{2}$ solutions. Scanning electron micrograph and $\mathrm{X}$-ray diffraction were used for anatomical characterization, whereas Fourier transform infrared spectroscopy was used for surface change characterization of adsorbents. Effects of different experimental parameters like $\mathrm{pH}$ (2-12), initial $\mathrm{Cr}(\mathrm{VI})$ concentration (100-900 $\mathrm{mg} / \mathrm{L})$, adsorbent dose $(2.5-20 \mathrm{~g} / \mathrm{L})$, contact time (15-360 $\mathrm{min})$ and temperature (288-318 K) were studied. Temperature increment was found to stimulate the adsorption process. Langmuir isotherm was found to give better representation over wide range of temperature for untreated, $\mathrm{H}_{3} \mathrm{PO}_{4}$ - as well as $\mathrm{ZnCl}_{2}$-treated teff straw, and Freundlich isotherm best represented the isotherm data for $\mathrm{NaOH}$-treated teff straw. Maximum $\mathrm{Cr}(\mathrm{VI})$ adsorption capacity of untreated, $\mathrm{NaOH}-, \mathrm{H}_{3} \mathrm{PO}_{4^{-}}$and $\mathrm{ZnCl}_{2}$-treated teff straw was found to be $86.1,73.8,89.3$ and $88.9 \mathrm{mg} / \mathrm{g}$, respectively. Respective values of average effective diffusion coefficient $\left(D_{\mathrm{e}}\right)$ were found to be $2.8 \times 10^{-13}$, $2.59 \times 10^{-14}, \quad 1.32 \times 10^{-13}$ and $1.14 \times 10^{-13} \mathrm{~m}^{2} / \mathrm{s}$, respectively. The negative value of $\Delta G_{\mathrm{o}}$ for all the adsorbents indicates $\mathrm{Cr}(\mathrm{VI})$ spontaneous adsorption. Isosteric
\end{abstract}

Editorial responsibility: J. Trögl

Electronic supplementary material The online version of this article (doi:10.1007/s13762-016-1080-6) contains supplementary material, which is available to authorized users.

V. C. Srivastava

vimalcsr@yahoo.co.in

1 Department of Chemical Engineering, Indian Institute of Technology Roorkee, Roorkee, Uttarakhand 247667, India heat of adsorption $\left(\Delta H_{\mathrm{st}, \mathrm{a}}\right)$ was found to vary with surface coverage $(\theta) . \Delta H_{\text {st,a }}$ increased for untreated, $\mathrm{H}_{3} \mathrm{PO}_{4^{-}}$and $\mathrm{ZnCl}_{2}$-treated teff straw, and decreased steadily with $\theta$ for $\mathrm{NaOH}$-treated teff straw.

Keywords Adsorption kinetics - Chemically modified adsorbent $\cdot$ Chromium removal Isosteric heat of adsorption · Isotherm study

\section{Introduction}

In the last few decades, interest has grown for the use of lignocellulosic materials for different applications (Jeffries and Jin 2000). Lignocellulosic biomass consists cellulose, hemicellulose and lignin which when separated can be used for different applications. Several types of pretreatment including physical (milling and grinding); chemical (acid, alkaline, oxidizing agent and organic solvent treatment); biological; and combination of physical and chemical techniques (steam pretreatment or auto hydrolysis, hydrothermolysis and wet oxidation) can be used for this purpose. Chemical pretreatment is one of the more efficient and cost-effective methods (Limayem and Ricke 2012; Agbor et al. 2011; Mosier et al. 2005).

Acid hydrolysis, alkaline hydrolysis, use of oxidation agent, organosolv method and ionic liquids can be used for chemical treatment depending upon the end-use. Acid pretreatment solubilizes hemicellulose and cellulose via hydrolysis reaction. Lignin is not hydrolyzed by acid, but it can be made soluble by alkali treatment, while organosolv treatment mainly focuses on solubilization of carbohydrates, and ionic liquid can dissolve both carbohydrates and lignin. Zinc chloride $\left(\mathrm{ZnCl}_{2}\right)$ is highly effective swelling reagent for biomass, separates hemicellulose from biomass 
Fig. 1 Flow diagram of chemical treatment on teff straw

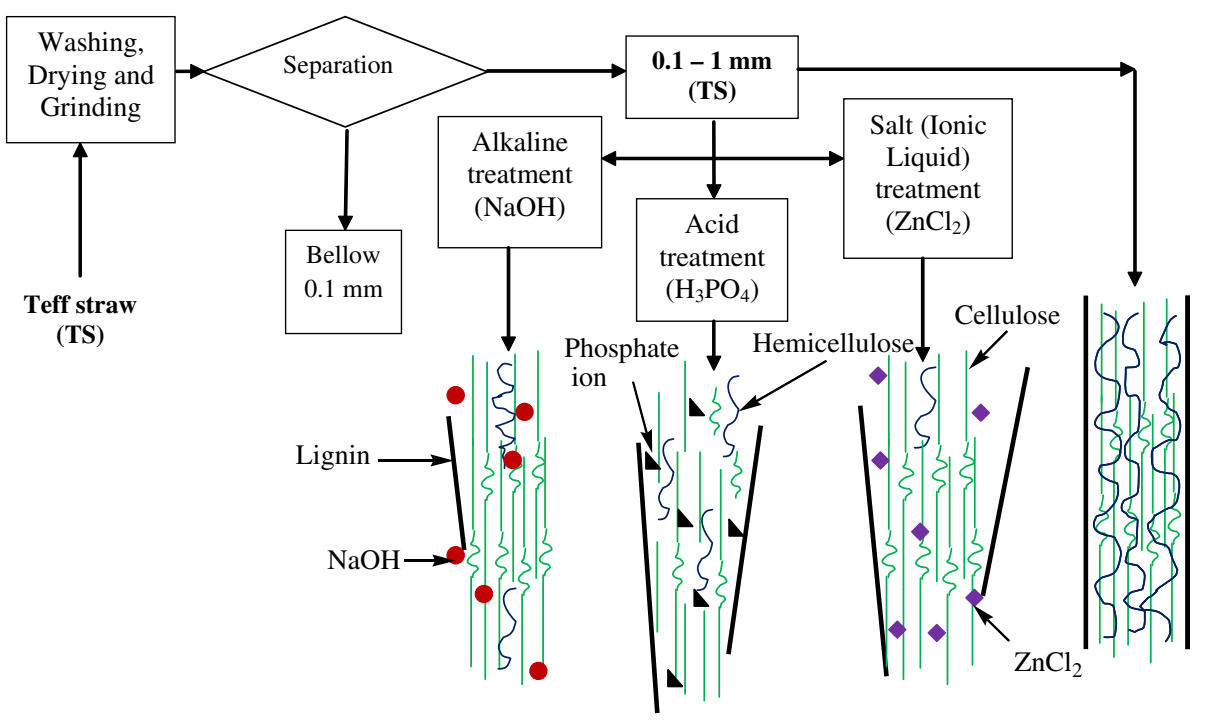

(Simkovic et al. 1994), and is highly selective for hemicellulose hydrolysis (Cao et al. 1995a). Zinc-cellulose complexes, formed due to reaction of zinc ions with carbohydrates, could be easily acid hydrolyzed. Acid hydrolysis hydrolyzes hemicellulose to monosaccharides (Cao et al. 1995b).

Chromium-based compounds are used in leather tanning, metal finishing and electroplating industries. Tanning industry is one of major polluting industries in developing countries such as India and Ethiopia (Wassie and Srivastava 2016). Environmental studies have shown that chromium is one of the most toxic dangerous heavy metal (Ali and Aboul-Enein 2002, 2006). Various researchers have reported $\mathrm{Cr}$ concentrations in the range of $500-1000 \mathrm{mg} / \mathrm{l}$ in untreated effluent from tanneries (Aravindhan et al. 2004; Garg et al. 2012). In Ethiopia, currently there are more than 30 tanneries under operation. From these tanneries, $2-40 \mathrm{mg} / \mathrm{L}$ concentration of chromium discharge has been reported (Wassie and Srivastava 2016). This is above the maximum concentration limit set by World Health Organization (WHO). For hexavalent chromium, discharge limit for surface water is $0.1 \mathrm{mg} / \mathrm{L}$ and that for potable water is $0.05 \mathrm{mg} / \mathrm{L}$ (WHO 2008).

Teff (Eragrostis tef) is one of the major food crops used in Ethiopia, and its annual yield is estimated to be about 15.5 million tones/year (Wassie and Srivastava 2016). Teff has very high amount of calcium content and is an excellent source of vitamin C. In the literature, a number of agricultural residues have been tested as adsorbent for chromium removal (Ali and Gupta 2006; Ali 2010, 2012; Ebrahimi et al. 2015; Kunquan et al. 2015; Shiow-Tien et al. 2014; Venkatesan et al. 2014; Doan et al. 2008; Martinez et al. 2015; Huang et al. 2015; Santos et al. 2016; Ali 2012; Elwakeel 2010). However, only few studies have been reported on use of teff straw as an adsorbent because of its less familiarity in scientific research world (Mulu 2013; Bezuayehu et al. 2014). Moreover, in these studies, only minor characterization like Fourier transform infrared (FTIR) of the teff straw was reported and detailed isotherm and thermodynamics were not reported.

Wassie and Srivastava (2016) used raw teff straw without any chemical modification for $\mathrm{Cr}(\mathrm{VI})$ removal. Since, chemical modifications are known to improve the characteristics of the adsorbents; therefore, this paper focuses on analyzing effect of chemical treatment on surface functional groups and anatomical structure of teff straw. Chemically treatment of teff straw was done by $\mathrm{NaOH}, \mathrm{H}_{3} \mathrm{PO}_{4}$ and $\mathrm{ZnCl}_{2}$ solutions. Batch experiments have been performed to study the effects of $\mathrm{pH}(2-12)$, initial $\mathrm{Cr}(\mathrm{VI})$ concentration (100-900 mg/L), adsorbent dose (2.5-20 g/L), contact time (15-360 $\mathrm{min})$ and temperature $(288-318 \mathrm{~K})$. Detailed kinetics, isotherm and thermodynamic modeling have been done using various models.

\section{Materials and methods}

\section{Adsorbent preparation and characterization}

Brown teff (mixture of red and white teff) straw collected from Ethiopia was washed with distilled water so as to remove dust. There is some variation on nutritional content between red and white teff seed (Seyfu 1997). The straw is identified as brown teff straw among other red and white teff straw from the residue teff seed during washing. Size of the dried teff straw was reduced in the range of $0.1-0.6 \mathrm{~mm}$ (named as untreated teff straw). This untreated teff straw was soaked with chemicals such as $\mathrm{NaOH}, \mathrm{H}_{3} \mathrm{PO}_{4}$ and $\mathrm{ZnCl}_{2}$. 
Treatment with chemicals was done by mixing $100 \mathrm{~g} / \mathrm{L}$ teff straw in chemical solutions for $2 \mathrm{~h}$ at $150 \mathrm{rpm}$ for each chemical. Dried samples were subjected to washing with warm $0.5 \mathrm{~N} \mathrm{HCl}$ solutions and followed by warm distilled water washing until $\mathrm{pH}$ became neutral. Straw to chemical weight ratio of 1:1 was used separately during modification and acid wash. Then the modified samples were named as $\mathrm{NaOH}, \mathrm{H}_{3} \mathrm{PO}_{4}$ and $\mathrm{ZnCl}_{2}$ treated teff straw. Figure 1 shows the flow chart of the modification process.

Elemental analysis was done using VarioMICRO CHNS analyzer. QUANTA Model 200 FEG USA scanning electron microscopy (SEM) was used for morphology analysis. Phillips diffraction unit (Model PW 1140/90) was used for X-ray diffraction (XRD) study of adsorbent. PerkinElmer (Pyris Diamond) thermo-gravimetric (TG) analyzer in temperature range from 20 to $1000{ }^{\circ} \mathrm{C}$ at a heating rate of $5{ }^{\circ} \mathrm{C} / \mathrm{min}$ under both an air and inert atmosphere was used for thermal decomposition analysis. Pellet (pressed-disk) technique was used over a spectral wave number range of 4000 to $400 \mathrm{~cm}^{-1}$ for FTIR analysis using Thermo Nicolet, model Magna 760.

\section{Adsorbate preparation and analytical measurement}

Potassium dichromate $\left(\mathrm{K}_{2} \mathrm{Cr}_{2} \mathrm{O}_{7}\right)$ was dissolved in distilled water to prepare aqueous solution of $\mathrm{Cr}(\mathrm{VI})$. Analytical reagent-grade potassium dichromate $\left(\mathrm{K}_{2} \mathrm{Cr}_{2} \mathrm{O}_{7}\right)$ was obtained from Ranbaxy Chemicals Ltd. India. UV-visible spectrophotometer (HACH DR 5000, USA) was used to determine chromium concentrations before and after treatment according to a standard colorimetric method in which absorbance of a pink complex formed between 1, 5-diphenylcarbazide and $\mathrm{Cr}(\mathrm{VI})$ was measured at $540 \mathrm{~nm}$ wavelength.

\section{Batch experimental procedure}

In every experiment, fixed amount of teff straw was added to $50 \mathrm{~mL}$ solution with known initial concentration and $\mathrm{pH}$. After the experiment, residual amount of chromium in the supernatant was determined. Adsorption experiments with the teff straw were carried out in batch phases with optimization of one parameter at a time. First effect of $\mathrm{pH}$ was studied, in which $\mathrm{pH}$ of the $100 \mathrm{mg} / \mathrm{L}$ initial $\mathrm{Cr}$ concentration solution was varied in the range of 2-12 using $0.1 \mathrm{M} \mathrm{HCl}$ and $0.1 \mathrm{M} \mathrm{NaOH}$. Experiments were carried out with buffer solution (citric acid, sodium hydroxide and chloride acid) which provided high buffer capacity with maximum deviation of $<5 \%$ from the adjusted $\mathrm{pH}$ value. Adsorbent dose was kept constant at $10 \mathrm{~g} / \mathrm{L}$, and contact time was $4 \mathrm{~h}$. Similarly, effect of adsorbent dose was studied in the range of $2.5-20 \mathrm{~g} / \mathrm{L}$ with $100 \mathrm{mg} / \mathrm{L}$ initial $\mathrm{Cr}(\mathrm{VI})$. For kinetic study, contact time was varied in the range of 15-360 min. Adsorption isotherm experiments were carried out by varying the initial $\mathrm{Cr}$ concentrations $(100-900 \mathrm{mg} / \mathrm{L})$ with constant adsorbent dose of $10 \mathrm{~g} / \mathrm{L}$ for $6 \mathrm{~h}$ at various temperatures of $15,25,35$ and $45^{\circ} \mathrm{C}$. Shaking speed of $150 \mathrm{rpm}$ in orbital shaking incubator was used for all experiments. Each experiment was done at least twice, and the average value has been used for calculation. For experimental error $\geq \pm 5 \%$, the experiment was redone.

Removal efficiency and the adsorption uptake in solid phase $\left(q_{\mathrm{t}}, \mathrm{mg} / \mathrm{g}\right)$ were calculated using the following relationships:

Removal efficiency $(\%)=\frac{\left(C_{\mathrm{o}}-C_{\mathrm{t}}\right)}{C_{\mathrm{o}}} 100$

$q_{\mathrm{t}}=\frac{\left(C_{\mathrm{o}}-C_{\mathrm{t}}\right)}{m} V$

where, $C_{\mathrm{o}}$ and $C_{\mathrm{t}}$ represent the initial and final $\mathrm{Cr}(\mathrm{VI})$ concentration $(\mathrm{mg} / \mathrm{L}), t$ represents contact time, $V$ represents volume of adsorbate solution (L) and $m$ represents the mass of teff straw $(\mathrm{g})$.

\section{Results and discussion}

\section{Adsorbent characterization}

Scanning electron microscopy (SEM) images of untreated and chemically treated teff straw are shown in Figure S1 at 500 times magnification. Comparison of raw teff straw image with that of $\mathrm{NaOH}$-modified teff straw image shows clear difference in the surface morphology. $\mathrm{NaOH}$-modified teff straw shows structure failure and cellulose dominant biomass. Phosphoric acid- and zinc chloride-modified teff straw show better porosity without much solid structure failure. SEM images (Figure S1) support removal of hemicelluloses after phosphoric acid treatment, removal of lignin and hemicelluloses with cellulose swelling from sodium hydroxide treatment, and selective removal of hemicelluloses from zinc chloride treatments (Cao et al. 1995a; Lopez-Linares et al. 2013; Taherdanak and Zilouei 2014; Xu et al. 2010).

Different studies show separate decomposition assumption for biomass components. First pectin decomposition occurs between 200 and $230{ }^{\circ} \mathrm{C}$, followed by hemicellulose up to $270{ }^{\circ} \mathrm{C}$ then celluloses $\left(240-350{ }^{\circ} \mathrm{C}\right)$ and finally lignin $\left(280-500{ }^{\circ} \mathrm{C}\right)$ (Mall et al. 2006). Thermal decomposition for untreated and chemically treated teff straw obtained by pyrolysis is shown in Figure S2. Alkaline, $\mathrm{NaOH}$-treated straw TG graph shows sharp loss of mass of about $5 \%$ (ash percentage) around $310{ }^{\circ} \mathrm{C}$ because of non-availability of lignin component, while other acids 

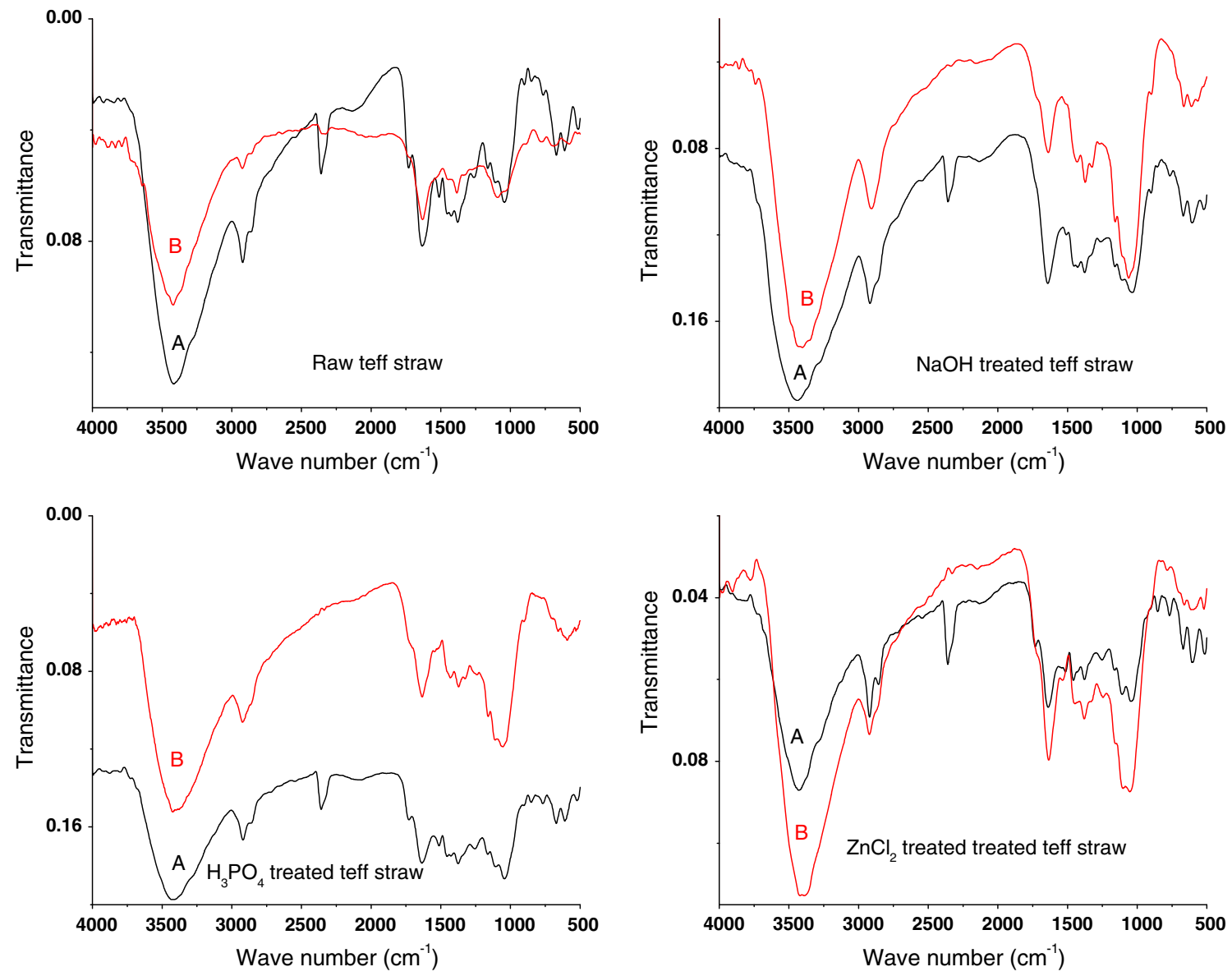

Fig. 2 FTIR spectra of adsorbents $(A)$ before and $(B)$ after chromium loading
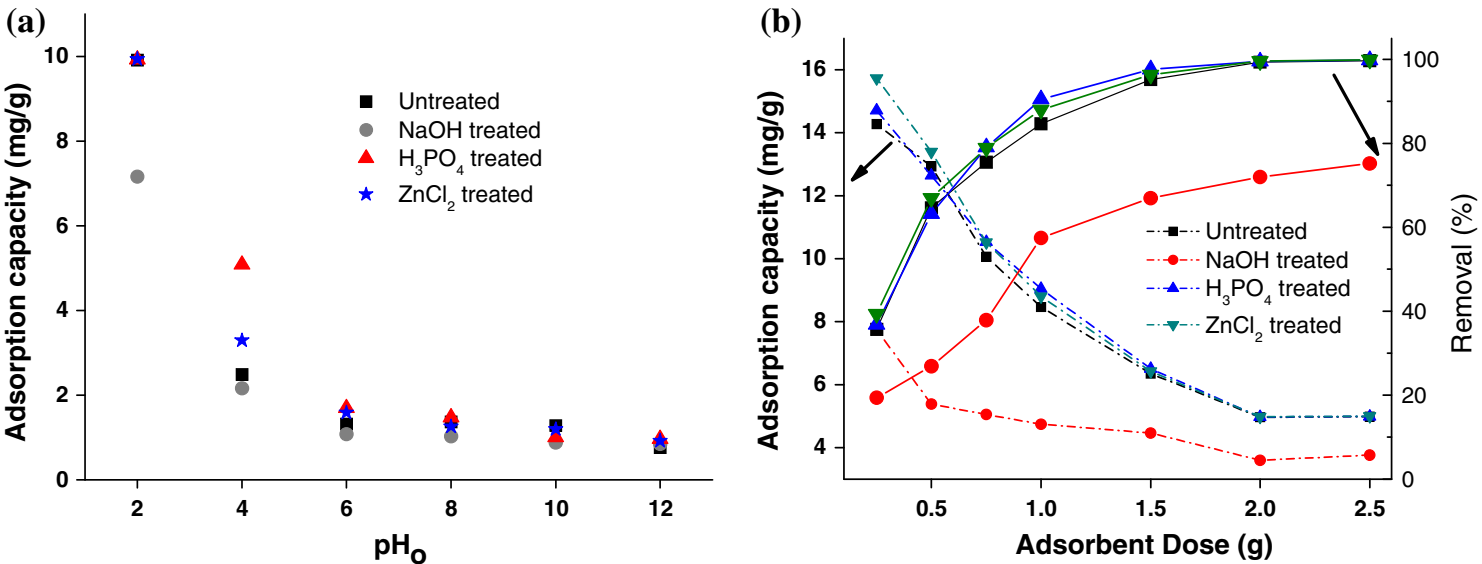

Fig. 3 Effect of a pH, and $\mathbf{b}$ adsorbent mass on the adsorption of $\mathrm{Cr}(\mathrm{VI})$ by untreated and chemically treated teff straw $\left(T=25{ }^{\circ} \mathrm{C}, t=4 \mathrm{~h}\right.$, $m=10 \mathrm{~g} / \mathrm{L}, C_{\mathrm{o}}=100 \mathrm{mg} / \mathrm{L}$ )

and $\mathrm{ZnCl}_{2}$ treated show $30-40 \%$ loss of mass of lignin and cellulosic component. Table $\mathrm{S} 1$ shows summary of thermogravimetric analysis for teff straw and its chemically treated derivatives.

Figure S3 shows the XRD diffraction patterns of raw and chemically treated samples of teff straw. Main peak appearing at $2 \theta$ value of $\sim 22^{\circ}$ indicates of the distance between hydrogen-bonded sheets in cellulose. Broad peak observed $\sim 16^{\circ}$ is known to be a composite of two peaks from $I_{\beta}\left(16.7^{\circ}\right.$ and $\left.14.9^{\circ}\right), I_{\alpha}\left(16.8^{\circ}\right.$ and $\left.14.3^{\circ}\right)$ or both (Yang et al. 2007). Small peak at $34.5^{\circ}$ may be due to ordering of one cellobiose unit along the fiber direction. 
Crystallinity index (CrI) is the measurement of fraction of crystalline material. CrI can be estimated using intensity of the peak at $\sim 22^{\circ}$ (as main peak) and the intensity of the peak at $\sim 18^{\circ}$ (between the main peak and the secondary peak at $\sim 16^{\circ}$ ) due to the amorphous portion:

$\mathrm{CrI}=\frac{I_{\text {Total }}-I_{\text {Amorphous }}}{I_{\text {Total }}}$

Relative change in CrI for unmodified and modified teff straw adsorbents is shown in Table S1. The CrI of untreated teff straw was found to be $52.01 \%$. There is an increase in CrI to $61.31 \%$ for $\mathrm{NaOH}$-treated teff straw due to the relatively high percentage amorphous removal (such as lignin) than other types of chemical treatment (Ngah et al. 2008). Debye-Scherrer equation (Eq. 4) was used to estimate crystallite size (Langford and Wilson 1978):

$B(2 \theta)=\frac{K \lambda}{L \cos \theta}$

where, $B$ is the breadth of the peak at half height (rad) of a specific phase (in this case at $2 \theta=22.2,22.3,22$ and 21.8 for raw, $\mathrm{NaOH}$ treated, $\mathrm{H}_{3} \mathrm{PO}_{4}$ treated, and $\mathrm{ZnCl}_{2}$ treated, respectively), $K=0.94), \lambda(1.542 \AA)$ is the wavelength of $\mathrm{X}$-ray, $\theta$ is the center angle of the peak and $L$ is the crystallite length. For raw, $\mathrm{NaOH}$-treated, $\mathrm{H}_{3} \mathrm{PO}_{4}$-treated and $\mathrm{ZnCl}_{2}$ treated teff straw, FWHM was $26 \times 10^{-3}, 9 \times 10^{-3}, 10 \times$ $10^{-3}$ and $33 \times 10^{-3} \mathrm{rad}$, respectively, and corresponding crystalline size was found to be about 110, 320, 290 and $90 \AA$ A XRD analysis shows that alkaline and acid treatment results in decrease in peak width and increase in its magnitude. This is due to amorphous lignin removal and higher crystallinity level of hydrolyzed cellulose (Park et al. 2010).

FTIR analysis is an important technique for identifying functional groups which help in adsorbing metal ions. Each part of biomass has different types and amount of functional groups which may be used in heavy metal adsorption. For example, aromatic rings and hydroxyl functional groups are dominantly available in lignin component of the biomass. Figure S4 highlights the percentage importance of each binding group in the mechanism of metal ion adsorption in the literature (Nurchi and Villaescusa 2011). Therefore, it is expected that peak strength increases in some functional groups due to the increment in surface area and loss of certain functional group due to removal of certain lignocellulosic part during chemical modification. Figure S5 shows the FTIR graph of raw and chemically treated teff straw. Compared to raw teff straw, the peak around $1730 \mathrm{~cm}^{-1}$ (due to carboxylic and carbonyl groups from aldehydes, ketones as well as aromatic rings mainly from lignin part) is not observed in $\mathrm{NaOH}-$ treated teff straw and shows intensity reduction for other chemical treatments due to lignin removal during the treatments. Amine group and $\mathrm{C}-\mathrm{H}$ functional group from $\mathrm{ZnCl}_{2}-$ treated teff straw show intensity reduction due to zinc and chloride ions reaction to these functional groups. Figure 2 shows the effect of chromium loading on the functional groups. Almost all functional groups show reduction in peak intensity with respect to chromium-loaded raw teff straw, while few peaks show intensity reduction during chromium loading on chemically treated teff straw. Extra capacity to handle more chromium loading in chemically treated teff straw than that in raw teff straw is due to the surface area improvement and surface functional groups increment. Observed peaks and their assigned functional groups due to chemical treatment and chromium loading have been summarized in Table S2 (Cheng et al. 2011; Teixeira et al. 2004; Mishra and Jha 2009).

\section{Adsorption parameter effects}

Solution $\mathrm{pH}$ can affect the adsorption process by affecting the speciation of metal in the solution and by changing the state of the active binding sites on biomass like teff straw. When the $\mathrm{pH}$ was decreased from 6 to 2, $\mathrm{Cr}(\mathrm{VI})$ sorption increased rapidly (Fig. 3a). It can be seen that no signification adsorption of $\mathrm{Cr}(\mathrm{VI})$ at $\mathrm{pH}$ greater than 6.0 was observed. This is because of the competition of $\mathrm{OH}^{-}$of aqueous solution with the anions species of hexavalent chromium for the adsorption sites.

Table 1 Pseudo-first- and pseudo-second-order parameters for the adsorption of $\mathrm{Cr}(\mathrm{VI})$ on different chemical treated adsorbent prepared from teff straw

\begin{tabular}{|c|c|c|c|c|c|c|c|}
\hline \multirow[t]{3}{*}{ Adsorbent from teff straw } & \multicolumn{7}{|c|}{ Kinetics parameters } \\
\hline & \multicolumn{3}{|c|}{ Pseudo-first-order $\frac{\mathrm{dq} \mathrm{q}_{\mathrm{t}}}{\mathrm{d} t}=k_{1}\left(q_{e}-q_{t}\right)$} & \multicolumn{4}{|c|}{ Pseudo-second-order $\frac{\mathrm{d} \mathrm{q}_{\mathrm{t}}}{\mathrm{d} t}=k_{2}\left(q_{e}-q_{t}\right)^{2}$} \\
\hline & $K_{1}(1 / \min )$ & $q_{\mathrm{e}}(\mathrm{mg} / \mathrm{g})$ & $R^{2}$ & $K_{2}(\mathrm{~g} / \mathrm{mg} \min ) \times 10^{3}$ & $q_{\mathrm{e}}(\mathrm{mg} / \mathrm{g})$ & $h(\mathrm{mg} / \mathrm{g} \min )$ & $R^{2}$ \\
\hline Untreated & 0.060 & 59.29 & 0.703 & 1.47 & 11.23 & 0.188 & 0.995 \\
\hline $\mathrm{NaOH}$ treated & 0.051 & 64.73 & 0.586 & 0.18 & 13.99 & 0.034 & 0.745 \\
\hline $\mathrm{H}_{3} \mathrm{PO}_{4}$ treated & 0.069 & 97.27 & 0.786 & 1.03 & 11.85 & 0.144 & 0.990 \\
\hline $\mathrm{ZnCl}_{2}$ treated & 0.081 & 122.72 & 0.875 & 1.56 & 11.11 & 0.193 & 0.997 \\
\hline
\end{tabular}

$q_{\mathrm{e}}$ is the concentration $\mathrm{Cr}(\mathrm{VI})$ adsorbed at equilibrium; $q_{\mathrm{t}}$ is the concentration $\mathrm{Cr}(\mathrm{VI})$ adsorbed at time $t ; k_{1}$ is rate constant for pseudo-first-order equation; and $k_{2}$ is the second-order rate constant for the pseudo-second-order equation 

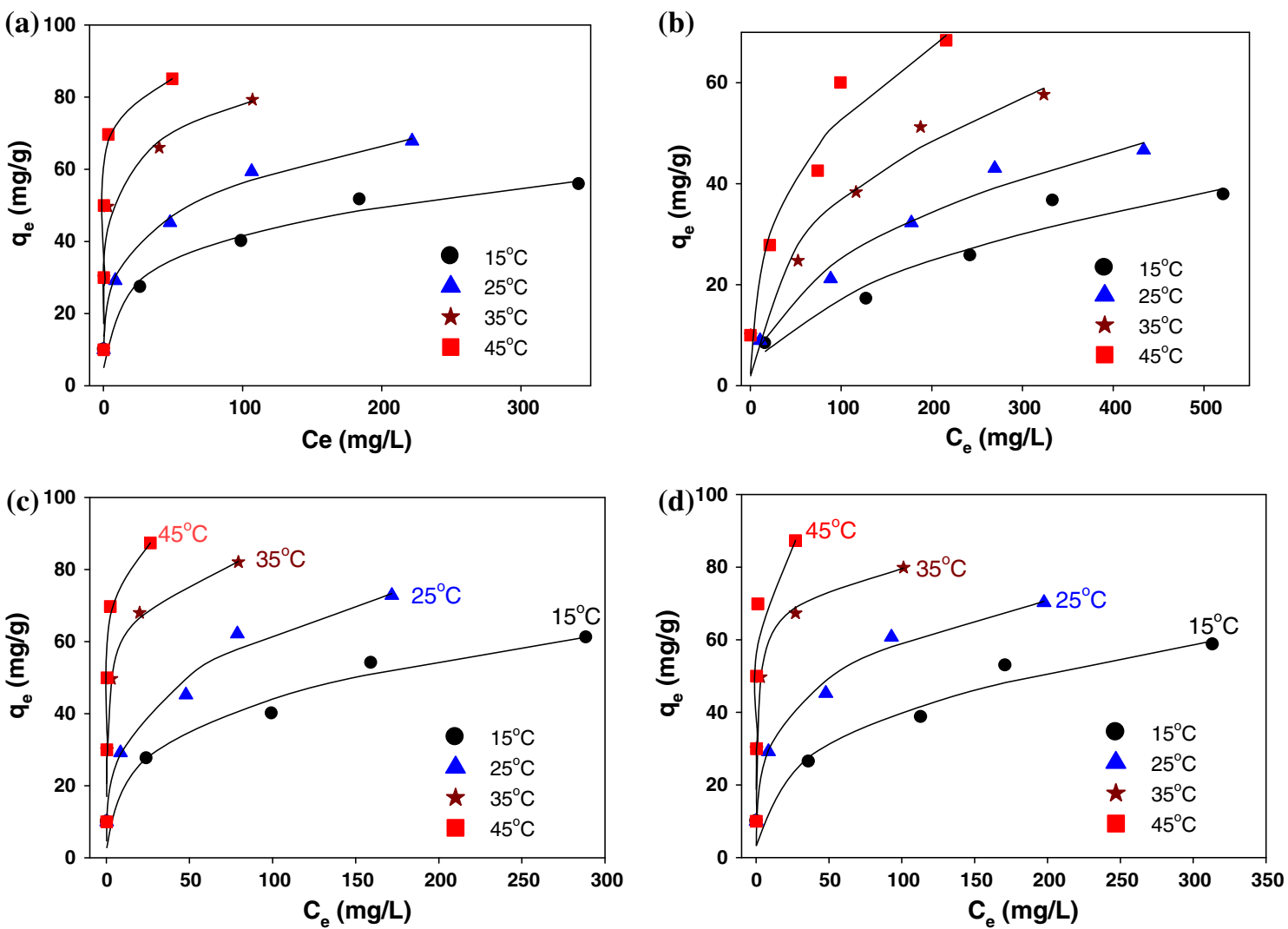

Fig. 4 Equilibrium adsorption isotherms at different temperatures for teff straw system, a untreated, $\mathbf{b} \mathrm{NaOH}$-treated, $\mathbf{c ~} \mathrm{H}_{3} \mathrm{PO}_{4}$-treated and d $\mathrm{ZnCl}_{2}$-treated teff straw. Experimental data points given by the

symbols and the lines predicted by the best-fit isotherm model; $\mathrm{pH}_{\mathrm{o}}$ : $2.0 ; m: 10 \mathrm{~g} / \mathrm{L}$

Effect of teff straw dosage on removal of $\mathrm{Cr}(\mathrm{VI})$ is shown in Fig. 3b. When the amount of teff straw added increased the sorption rate of $\mathrm{Cr}(\mathrm{VI})$ also increased. Except $\mathrm{NaOH}$-treated teff straw, chromium removal efficiency was above $85 \%$ at $10 \mathrm{~g} / \mathrm{L}$. At higher dose of teff straw, removal efficiency became stable showing a low sorption rate increment per increment of straw adsorbent dose. Also at higher dose, more sorption sites are available without saturation; however, due to the fixed total chromium quantity which is available for removal, $\mathrm{Cr}$ adsorption per mass of straw adsorbent decreased at higher dosage.

The contact time for exchange of adsorbate from solution to the adsorbent is very important factor in the adsorption treatment process. Uptake of $\mathrm{Cr}(\mathrm{VI})$ species was initially fast due to the large availability of vacant surface sites, and uptake rate became slow when the adsorption reached equilibrium. There was fast removal over $50 \%$ in the first hour and reached above $90 \%$ in $4 \mathrm{~h}$ for $\mathrm{H}_{3} \mathrm{PO}_{4}$, $\mathrm{ZnCl}_{2}$ and untreated (raw) teff straw adsorbent. Removal efficiency was found to be comparatively less (about $20 \%$ in $1 \mathrm{~h}$ and $70 \%$ in $6 \mathrm{~h}$ ) for $\mathrm{NaOH}$-treated teff straw.

$\mathrm{NaOH}$-treated teff straw showed low removal efficiency mainly because removal of amorphous lignin during the

treatment with $\mathrm{NaOH}$ caused structural failure and loss of significant amount of functional groups that have high affinity toward metal ions.

\section{Adsorption kinetics}

Adsorption rate is described by adsorption kinetics which is an important characteristic for evaluating the adsorption process. In this study, pseudo-first-order and pseudo-second-order models were applied (Gurgel et al. 2009). When sorption rate follows an assumption that the rate of occupation of adsorption sites is proportional to the square of number of unoccupied sites, it is called pseudo-secondorder kinetic rate (Ho 2004; Ho and McKay 1998). Both equations are given in Table 1. Kinetic parameter values are shown in Table 1 for both pseudo-first-order and pseudo-second-order kinetics. $R^{2}$ values show pseudosecond-order kinetics gave better fitting than pseudo-firstorder kinetics model and high initial adsorption rate, $\left(k_{2} q_{\mathrm{e}}^{2}\right)$, value from $\mathrm{ZnCl}_{2}$-treated and untreated teff straw adsorbent 0.193 and $0.188 \mathrm{mg} / \mathrm{g} \mathrm{min}$, respectively, and for $\mathrm{NaOH}$-treated teff straw, the initial adsorption rate is only $0.034 \mathrm{mg} / \mathrm{g} \mathrm{min}$. 
Table 2 Isotherm parameters for $\mathrm{Cr}(\mathrm{VI})$ adsorption onto teff straw adsorbents at different temperatures

\begin{tabular}{|c|c|c|c|c|c|c|c|c|c|c|c|c|}
\hline \multirow{2}{*}{$\begin{array}{l}\text { Temperature }(\mathrm{K}) \\
\text { Langmuir } \\
q_{\mathrm{e}}=\frac{q_{\max } b C_{\mathrm{e}}}{1+b C_{\mathrm{e}}}\end{array}$} & \multicolumn{3}{|c|}{ Untreated } & \multicolumn{3}{|c|}{$\mathrm{NaOH}$ treated } & \multicolumn{3}{|c|}{$\mathrm{H}_{3} \mathrm{PO}_{4}$ treated } & \multicolumn{3}{|c|}{$\mathrm{ZnCl}_{2}$ treated } \\
\hline & $\begin{array}{l}q_{\max } \\
(\mathrm{mg} / \mathrm{g})\end{array}$ & $b(\mathrm{~L} / \mathrm{mg})$ & $R^{2}$ & $\begin{array}{l}q_{\max } \\
(\mathrm{mg} / \mathrm{g})\end{array}$ & $b(\mathrm{~L} / \mathrm{mg})$ & $R^{2}$ & $\begin{array}{l}q_{\max } \\
(\mathrm{mg} / \mathrm{g})\end{array}$ & $b(\mathrm{~L} / \mathrm{mg})$ & $R^{2}$ & $\begin{array}{l}q_{\max } \\
(\mathrm{mg} / \mathrm{g})\end{array}$ & $b(\mathrm{~L} / \mathrm{mg})$ & $R^{2}$ \\
\hline 288 & 58.4 & 0.0426 & 0.986 & 47.9 & 0.0066 & 0.897 & 64.3 & 0.0360 & 0.965 & 62.9 & 0.0282 & 0.956 \\
\hline 298 & 70.1 & 0.0763 & 0.988 & 57 & 0.0095 & 0.950 & 76.3 & 0.0679 & 0.971 & 73.1 & 0.0716 & 0.982 \\
\hline 308 & 79.3 & 0.4470 & 0.995 & 63.6 & 0.0209 & 0.935 & 83.2 & 0.5611 & 0.998 & 80.6 & 0.5277 & 0.998 \\
\hline 318 & 86.1 & 1.6597 & 0.999 & 73.8 & 0.0385 & 0.947 & 89.3 & 1.7157 & 0.999 & 88.9 & 2.0022 & 0.999 \\
\hline $\begin{array}{l}\text { Freundlich } \\
q_{e}=k_{f} C_{e}^{1 / n}\end{array}$ & $k_{f}(\mathrm{~L} / \mathrm{mg})$ & $n$ & $R^{2}$ & $k_{f}(\mathrm{~L} / \mathrm{mg})$ & $n$ & $R^{2}$ & $k_{f}(\mathrm{~L} / \mathrm{mg})$ & $n$ & $\mathrm{R}^{2}$ & $k_{f}(\mathrm{~L} / \mathrm{mg})$ & $n$ & $R^{2}$ \\
\hline 288 & 13.7 & 4.2 & 0.992 & 2.2 & 2.2 & 0.964 & 13.8 & 4.0 & 0.984 & 13.4 & 4.1 & 0.966 \\
\hline 298 & 17.2 & 3.9 & 0.999 & 2.9 & 2.2 & 0.988 & 17.3 & 3.7 & 0.991 & 17.2 & 3.8 & 0.996 \\
\hline 308 & 28.3 & 4.0 & 0.805 & 13 & 4.3 & 0.937 & 29.3 & 3.6 & 0.826 & 28.7 & 3.9 & 0.813 \\
\hline 318 & 37.7 & 3.6 & 0.646 & 16 & 4 & 0.958 & 40.4 & 3.1 & 0.669 & 42.1 & 3.2 & 0.613 \\
\hline
\end{tabular}

\section{Determination of diffusivity}

Boyd et al. (1947) model (assuming the adsorbent particles to be spherical having radius $\left.\left(R_{\mathrm{a}}, \mathrm{m}\right)\right)$, given by following expression, could be used to determine the effective diffusion coefficient $\left(D_{\mathrm{e}}, \mathrm{m}^{2} / \mathrm{s}\right)$ from the kinetic data:

$F(t)=1-\frac{6}{\pi^{2}} \sum_{z=1}^{\infty} \frac{1}{z^{2}} \exp \left(\frac{-z^{2} \pi^{2} D_{\mathrm{e}} t}{R_{\mathrm{a}}^{2}}\right)$

where, $F(t)=q_{t} / q_{\mathrm{e}}$ is at time $t$, and $z$ is an integer. The average radius from sieve analysis is $0.15 \mathrm{~mm}$ for raw teff straw and its chemically impregnated derivatives as: $0.07 \mathrm{~mm}$ for $\mathrm{NaOH}$ and about $0.1 \mathrm{~mm}$ for both $\mathrm{H}_{3} \mathrm{PO}_{4}$ and $\mathrm{ZnCl}_{2}$ impregnated. Vermeulen's approximation (Vermeulen 1953) given by Eq. (5) fits the whole range $0<F(t)<1$.

$F(t)=\left[1-\exp \left(\frac{-\pi^{2} D_{\mathrm{e}} t}{R_{\mathrm{a}}^{2}}\right)\right]^{1 / 2}$

This equation could further be simplified for calculating $D_{\text {e. }}$.

$\ln \left[\frac{1}{\left(1-F^{2}(t)\right)}\right]=\frac{\pi^{2} D_{\mathrm{e}} t}{R_{\mathrm{a}}^{2}}$

Thus, $D_{\mathrm{e}}$ is obtained from the slope of $\ln \left[1 /\left(1-F^{2}(t)\right)\right]$ versus $t$ plot. The average values of $D_{\mathrm{e}}$ has been found to be $2.8 \times 10^{-13}, \quad 2.59 \times 10^{-14}, \quad 1.32 \times 10^{-13}$ and $1.14 \times 10^{-13} \mathrm{~m}^{2} / \mathrm{s}$ for raw, $\mathrm{NaOH}-, \mathrm{H}_{3} \mathrm{PO}_{4^{-}}$and $\mathrm{ZnCl}_{2^{-}}$ treated teff straw adsorbents, respectively.

\section{Effect of temperature}

Figure 4 shows plots of adsorption isotherms for $\mathrm{Cr}(\mathrm{VI})$-teff straw adsorbents at different temperatures of 288, 298, 308 and $318 \mathrm{~K}$. It is observed that the sorption of $\mathrm{Cr}(\mathrm{VI})$ increased with an increase in temperature. This is because an increase in temperature increases the mobility of $\mathrm{Cr}(\mathrm{VI})$ with better diffusion characteristics. This results in enhancement in the adsorptive capacity of the adsorbent. However, during the adsorption process, diffusion of the metal ions through the pores of the adsorbents is not the only rate-controlling step; therefore, the endothermic nature of the adsorption may be due to chemisorptive nature of the adsorption process.

Adsorbent binding site characteristics like structure, functional groups, surface properties; and nature of adsorbates such as molecular structure, concentration, standard redox potential, size, weight, as well as charge of the ion are important factors in addition to solution chemistry (like ionic strength, $\mathrm{pH}$ ).

\section{Adsorption equilibrium study}

The experimental adsorption equilibrium isotherm data have been fitted to Langmuir and Freundlich models. Langmuir isotherm is based on assumption that sorption will take place at specific homogeneous sites of the adsorbents, while Freundlich isotherm considers heterogeneous and non-uniform heat of adsorption distribution on the adsorbent surface (Srivastava et al. 2007). Both equations and their respective parameters, and $R^{2}$ values are shown in Table 2. Langmuir isotherm represents most of the adsorption data at wide variety of temperature range for untreated and $\mathrm{H}_{3} \mathrm{PO}_{4}{ }^{-}$and $\mathrm{ZnCl}_{2}$-treated teff straw adsorbent, while Freundlich isotherm shows slightly better fitting for $\mathrm{NaOH}$-treated teff straw adsorbent and at $288 \mathrm{~K}$.

\section{Estimation of thermodynamic parameters}

Classical thermodynamics gives the following relationship between Gibbs free energy change $\left(\Delta G_{\mathrm{o}}, \mathrm{kJ} / \mathrm{mol}\right)$, the 


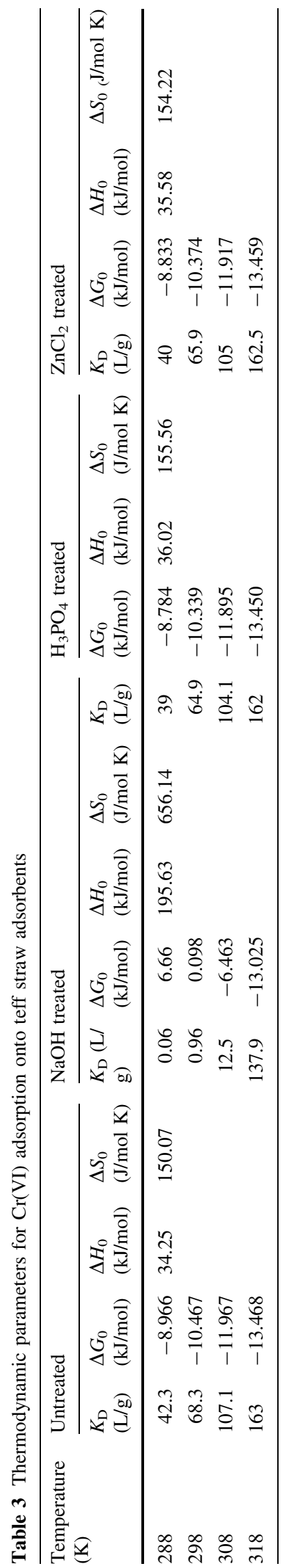

entropy change $\left(\Delta S_{\mathrm{o}}, \mathrm{kJ} / \mathrm{mol} \mathrm{K}\right)$ and the enthalpy change $\left(\Delta H_{\mathrm{o}}, \mathrm{kJ} / \mathrm{mol}\right)$ :

$-\frac{\Delta G_{\mathrm{o}}}{R T}=\frac{\Delta S_{\mathrm{o}}}{R}-\frac{\Delta H_{\mathrm{o}}}{R T}=\ln K_{\mathrm{D}}$

where, $K_{\mathrm{D}}\left(q_{\mathrm{e}} / C_{\mathrm{e}}\right)$ is linear sorption distribution coefficient obtained from the intercept of the $\ln \left(q_{\mathrm{e}} / C_{\mathrm{e}}\right)$ versus $q_{\mathrm{e}}$ plot. $\Delta H_{\mathrm{o}}$ (also called isosteric heat of adsorption $\left(\Delta H_{\mathrm{st}, \mathrm{o}}\right)$ with zero surface coverage) was determined from the slope of $\ln$ $K_{\mathrm{D}}$ versus (1/T) plot (Suzuki and Fujii 1982). Values of $\Delta G_{\mathrm{o}}, \Delta H_{\mathrm{o}}$ and $\Delta S_{\mathrm{o}}$ have been estimated and are shown in Table 3. $\Delta H_{\mathrm{o}}$ was found to be positive indicating endothermic adsorption process. This may be due to the fact that metal ions have to displace water and other molecules for its adsorption. The positive value and magnitude of $\Delta S_{\mathrm{o}}$ tell the degree of randomness at the adsorbent-solution interface and an affinity of the adsorbents toward $\mathrm{Cr}(\mathrm{VI})$ ions. $\Delta G_{\mathrm{o}}$ values were negative indicating the spontaneous and feasible adsorption process.

\section{Isosteric heat of adsorption}

For constant $q_{\mathrm{e}}(10,20,30,40,50 \mathrm{mg} / \mathrm{g})$ of teff straw adsorbents, the apparent isosteric heat of adsorption $\left(\Delta H_{\text {st,a }}\right)$ was calculated using Clausius-Clapeyron equation (Raymon 1998):

$\frac{-\Delta H_{\mathrm{st}, \mathrm{a}}}{R T^{2}}=\left[\frac{d \ln C_{\mathrm{e}}}{\mathrm{d} T}\right]$

In this case, $C_{\mathrm{e}}$ at constant $q_{\mathrm{e}}$ at different temperatures was obtained from the best-fit isotherm model which was further used to plot isosters (shown in Fig. 5) at different $q_{\mathrm{e}}$ for $\mathrm{Cr}(\mathrm{VI}) . \Delta H_{\text {st, a }}$ values (calculated from slope of the $\operatorname{lnC}_{\mathrm{e}}$ versus $(1 / T)$ plot) and $R^{2}$ values are presented in Table 4 . $R^{2}$ values shown in Table 4 confirm good representation of experimental data by Eq. (9). Figure S6 shows that values of $\Delta \mathrm{H}_{\mathrm{st}, \mathrm{a}}$ varies with surface loadings for $\mathrm{Cr}(\mathrm{VI})$-adsorbent systems indicating heterogeneous nature of the adsorbent surface. It may be noted that the $\Delta \mathrm{H}_{\mathrm{st}, \mathrm{a}}$ is obtained after subtracting the heat of solution $\left(\Delta \mathrm{H}_{\mathrm{sol}}\right)$ and the heat of adsorption of water $\left(\Delta H_{\mathrm{w}}\right)$ from the net isosteric heat of adsorption $\left(\Delta H_{\text {st,net }}\right)$ :

$\Delta H_{\mathrm{st}, \mathrm{a}}=\Delta H_{\mathrm{st}, \mathrm{net}}-\Delta H_{\mathrm{sol}}-f \Delta H_{\mathrm{W}}$

where, $f$ is the number of moles of water exchanged per mole of adsorbate. $\Delta H_{\mathrm{w}}$ is normally assumed to be zero, and $\Delta H_{\text {sol }}$ for potassium dichromate is $17.4 \mathrm{~kJ} / \mathrm{mol} . \Delta H_{\text {st, net }}$ values calculated from Eq. (10) are given in Table 4.

\section{Regeneration study}

Regeneration of spent untreated and chemically treated teff straw was carried out by washing them three times 

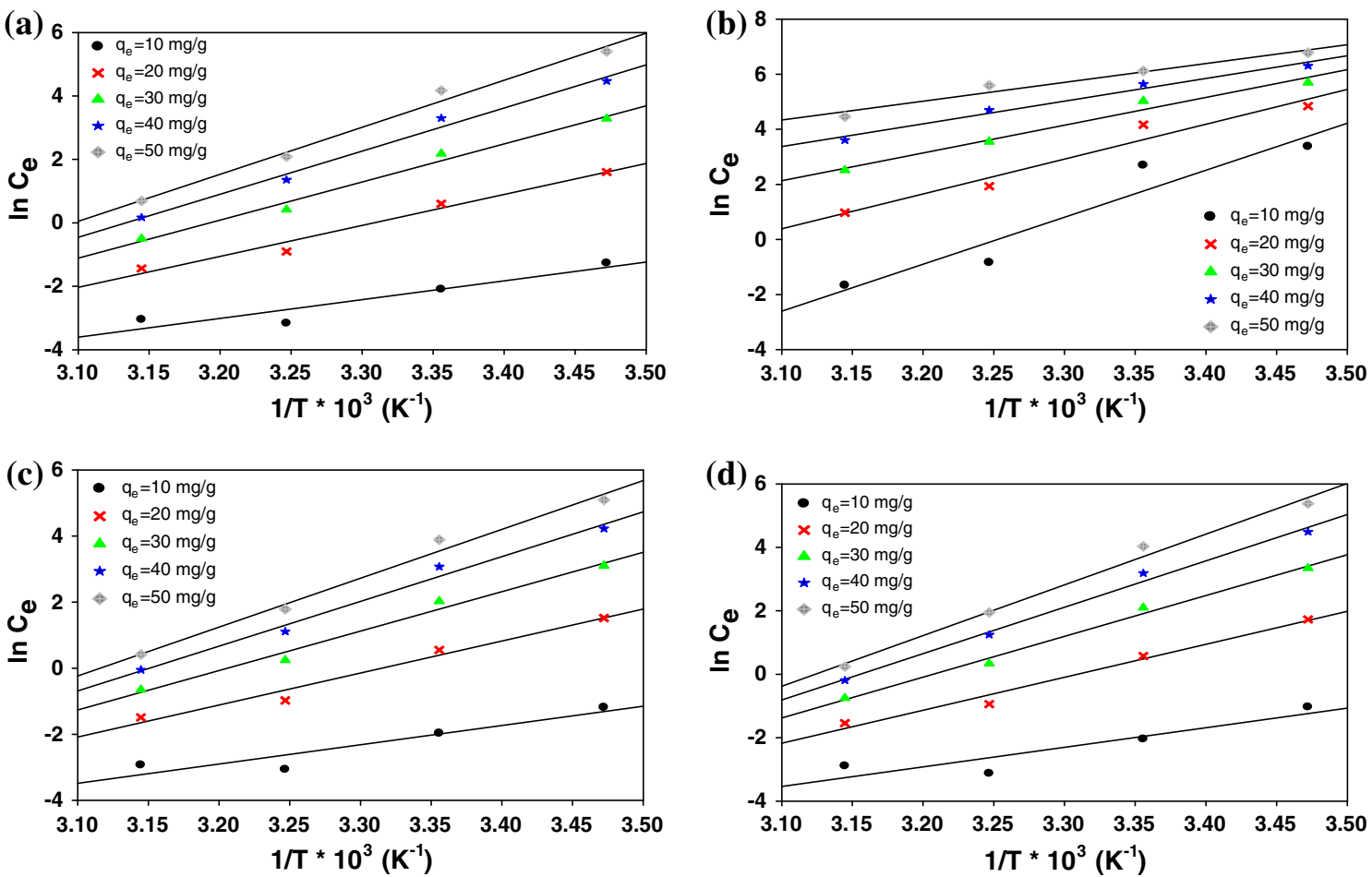

Fig. 5 Adsorption isosters' for determining isosteric heat of adsorption, a untreated, b $\mathrm{NaOH}$-treated, $\mathbf{c} \mathrm{H}_{3} \mathrm{PO}_{4}$-treated, $\mathbf{d} \mathrm{ZnCl}_{2}$-treated teff straw

Table 4 Isosteric enthalpy for $\mathrm{Cr}(\mathrm{VI})$ adsorption onto teff straw adsorbents

\begin{tabular}{|c|c|c|c|c|c|c|c|c|c|c|c|c|}
\hline \multirow[t]{2}{*}{$q_{\mathrm{e}}(\mathrm{mg} / \mathrm{g})$} & \multicolumn{3}{|l|}{ Untreated } & \multicolumn{3}{|c|}{$\mathrm{NaOH}$ treated } & \multicolumn{3}{|c|}{$\mathrm{H}_{3} \mathrm{PO}_{4}$ treated } & \multicolumn{3}{|c|}{$\mathrm{ZnCl}_{2}$ treated } \\
\hline & $\begin{array}{l}\Delta H_{\mathrm{st}, \mathrm{a}} \\
(\mathrm{kJ} / \mathrm{mol})\end{array}$ & $\begin{array}{l}\Delta H_{\text {st,net }} \\
(\mathrm{kJ} / \mathrm{mol})\end{array}$ & $R^{2}$ & $\begin{array}{l}\Delta H_{\mathrm{st}, \mathrm{a}} \\
(\mathrm{kJ} / \mathrm{mol})\end{array}$ & $\begin{array}{l}\Delta H_{\text {st,net }} \\
(\mathrm{kJ} / \mathrm{mol})\end{array}$ & $R^{2}$ & $\begin{array}{l}\Delta H_{\mathrm{st}, \mathrm{a}} \\
(\mathrm{kJ} / \mathrm{mol})\end{array}$ & $\begin{array}{l}\Delta H_{\text {st,net }} \\
(\mathrm{kJ} / \mathrm{mol})\end{array}$ & $R^{2}$ & $\begin{array}{l}\Delta H_{\mathrm{st}, \mathrm{a}} \\
(\mathrm{kJ} / \mathrm{mol})\end{array}$ & $\begin{array}{l}\Delta H_{\text {st,net }} \\
(\mathrm{kJ} / \mathrm{mol})\end{array}$ & $R^{2}$ \\
\hline 10 & 5.92 & 23.32 & 0.880 & 17.06 & 34.46 & 0.916 & 5.84 & 23.24 & 0.874 & 6.16 & 23.56 & 0.839 \\
\hline 20 & 9.75 & 27.15 & 0.976 & 12.65 & 30.05 & 0.954 & 9.69 & 27.09 & 0.973 & 10.39 & 27.79 & 0.981 \\
\hline 30 & 11.99 & 29.39 & 0.986 & 10.08 & 27.48 & 0.976 & 11.93 & 29.33 & 0.985 & 12.86 & 30.26 & 0.992 \\
\hline 40 & 13.59 & 30.99 & 0.988 & 8.25 & 25.65 & 0.981 & 13.53 & 30.93 & 0.987 & 14.62 & 32.02 & 0.992 \\
\hline 50 & 14.82 & 32.22 & 0.988 & 6.83 & 24.23 & 0.962 & 14.77 & 32.17 & 0.987 & 15.98 & 33.38 & 0.990 \\
\hline
\end{tabular}

with hot water $(383 \mathrm{~K})$ and followed by washing with $0.1 \mathrm{M} \mathrm{H}_{2} \mathrm{SO}_{4}$ solution (20 g spent adsorbent in one liter for $30 \mathrm{~min}$ ). This adsorption-regeneration cycle was performed for four number of cycles (Fig. 6). The considerable improvement in $\mathrm{Cr}(\mathrm{VI})$ removal efficiencies was observed for $\mathrm{NaOH}$-treated adsorbent after hot water$\mathrm{H}_{2} \mathrm{SO}_{4}$ solution regeneration (Fig. 6a). This may be due to change in adsorbent surface $\mathrm{pH}$ chemistry. Approximately, 60-80\% mass recovery (with respect to the initial adsorbent mass) was observed after the fourth cycle (Fig. 6b). This is because of teff straw is tiny in structure, and its residues have a tendency of easily crack into more additional acid solution and hydrothermal solubility of some low polymerized lignin and hemicelluloses as well as other extractives.

\section{Adsorption mechanism and comparative assessment}

$\mathrm{Cr}(\mathrm{VI})$ removal from aqueous solution by a biomass could be through two mechanisms (Park et al. 2005). In first mechanism, $\mathrm{Cr}(\mathrm{VI})$ gets directly reduced to $\mathrm{Cr}(\mathrm{III})$ by electron-donor functional groups. In second mechanism, $\mathrm{Cr}(\mathrm{VI})$ binds to the positively charged groups like amino and carboxyl groups (their existence in teff straw is confirmed by FTIR analysis) and further gets reduced to $\mathrm{Cr}$ (III) (by adjacent electron-donor groups) which further gets released into the aqueous phase due to electronic repulsion between the positively charged groups. Figure 7 shows proposed chromium removal mechanism by teff straw.

A number of studies have been conducted using raw (virgin) plant wastes or biochar as adsorbents. Only few 

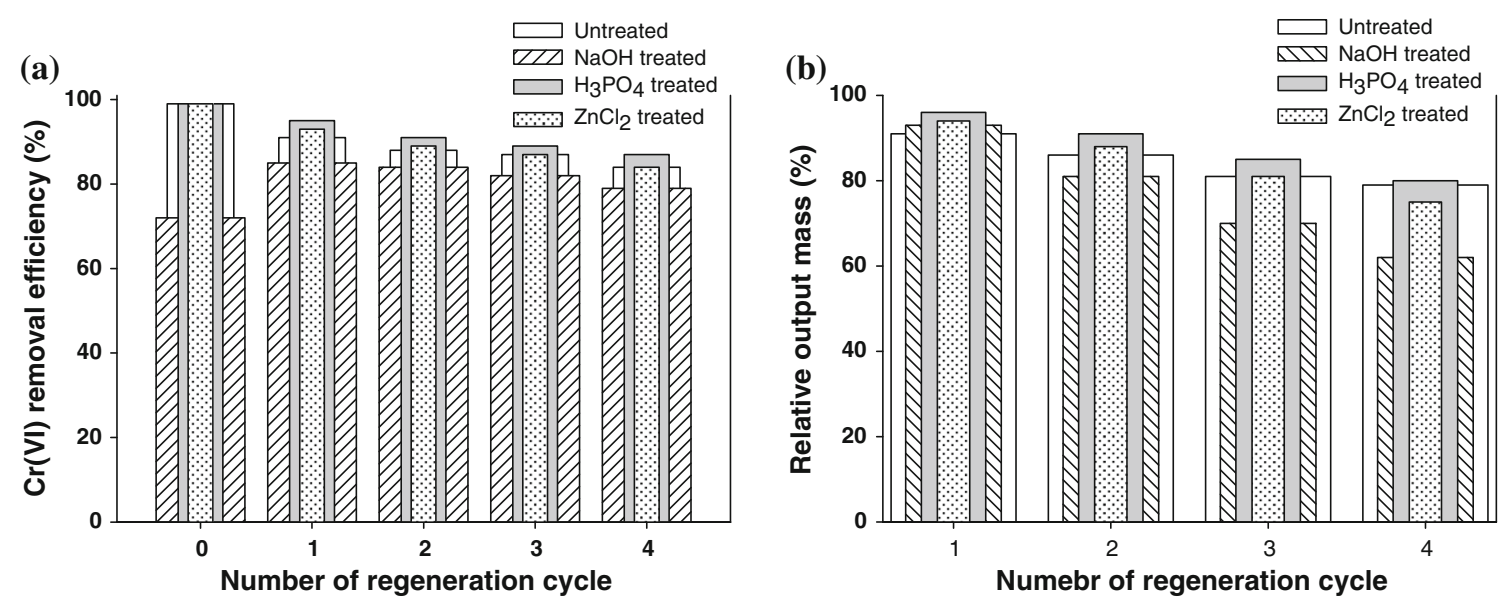

Fig. 6 a $\mathrm{Cr}(\mathrm{VI})$ removal efficiency, and $\mathbf{b}$ regenerated adsorbent mass recovery (\%) during various cycles of regeneration of the adsorbents by hot water and sulfuric acid solution

Fig. 7 Proposed chromium removal mechanism by teff straw
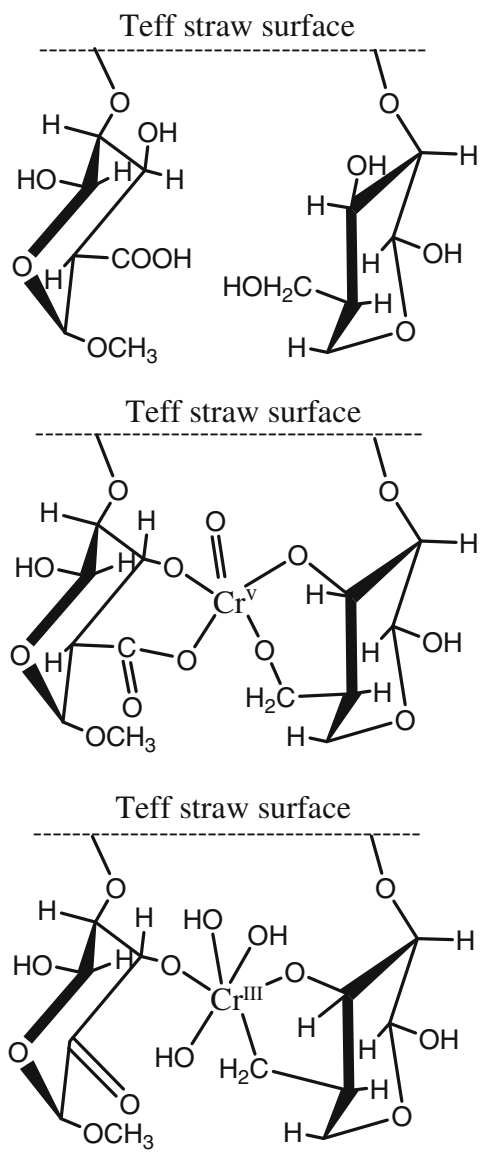
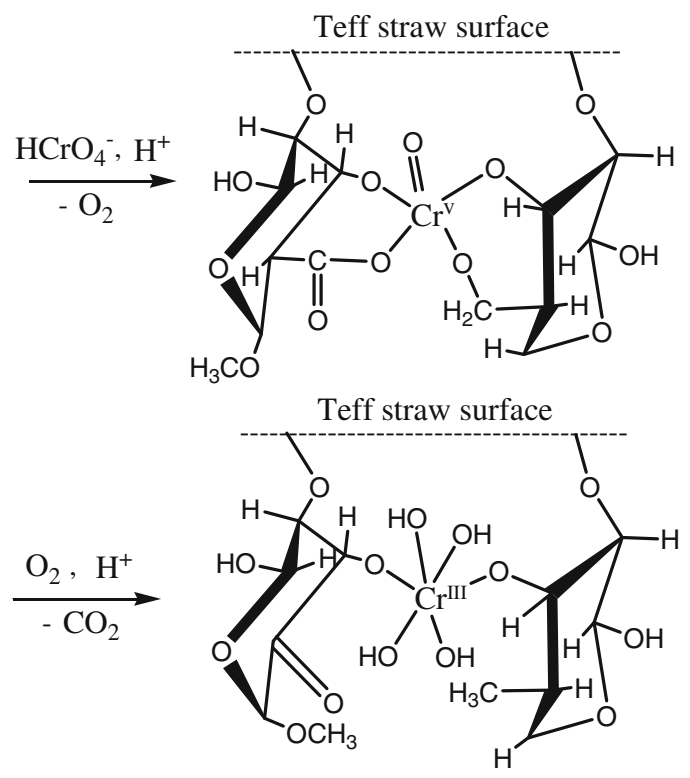

Teff straw surface

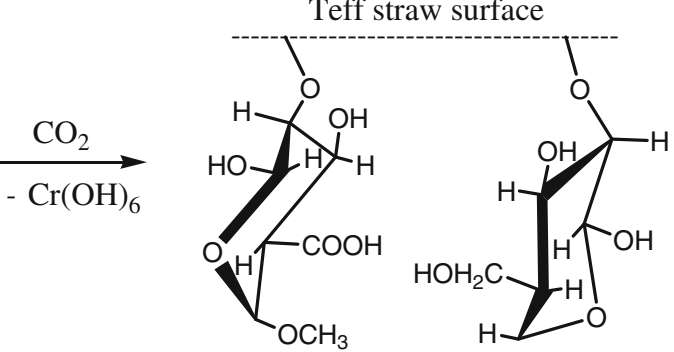

studies are available in which chemical treated plant materials have been used. Comparative assessment of agricultural residues for $\mathrm{Cr}(\mathrm{VI})$ removal is shown in Fig. 8 (Sharma and Forster 1994; Dakiky et al. 2002; Gonzalez et al. 2008; Anandkumar and Mandal 2009; Bansal et al. 2009; Dhir and Kumar 2010; Rao and Rehman 2010; Blanes et al. 2016). It may be seen in the figure that adsorption capacity of these biomass-based low-cost adsorbents varies in the range of
$5-80 \mathrm{mg} / \mathrm{g}$ for adsorption experiments carried out at 298-303 K. Teff straw has better adsorption capacity than most of the adsorbents; however, a few have better adsorption capacity than teff straw as well. It may be noted that a direct comparison of adsorption capacity of these adsorbents is not justified as the adsorption experiments have been carried out different conditions of time, $\mathrm{pH}$, etc. It should be noted that regeneration of the biomass-based adsorbent has not been 


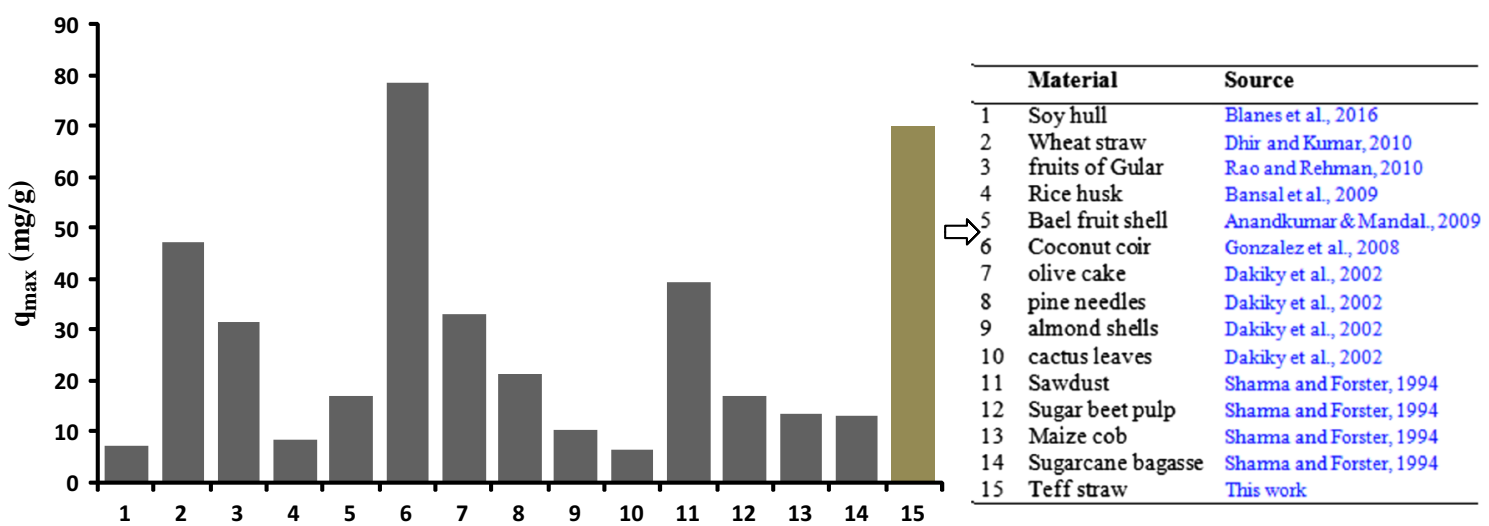

Fig. 8 Maximum adsorption capacities for virgin biomass residues at 298-303 K

reported in most of the previous studies, and based on the present work, it seems that the teff straw can be reused for four number of cycles with significant adsorption capacity.

\section{Conclusion}

Various characterization techniques confirmed removal of hemicelluloses from teff straw after phosphoric acid treatment, removal of lignin and hemicelluloses with cellulose swelling from sodium hydroxide treatment, and selective removal of hemicelluloses from zinc chloride treatment of teff straw. Equilibrium isotherms were analyzed at various temperature ranges, and Langmuir isotherm was found to give good representation over wide range of temperature for untreated, $\mathrm{H}_{3} \mathrm{PO}_{4}$ treated as well as $\mathrm{ZnCl}_{2}$ treated. For untreated, $\mathrm{H}_{3} \mathrm{PO}_{4}$-treated, $\mathrm{ZnCl}_{2}$-treated and $\mathrm{NaOH}$-treated teff straw, maximum adsorption capacity from Langmuir isotherm model increased from 58.4, 47.9, 64.3, $62.9 \mathrm{mg} / \mathrm{g}$ at $288 \mathrm{~K}$ to $86.1,73.8,89.3,88.9 \mathrm{mg} / \mathrm{g}$, respectively, at $318 \mathrm{~K}$. Cr(VI) adsorption onto all the adsorbents was endothermic in nature. The negative value of $\Delta G_{\mathrm{o}}$ indicates spontaneous adsorption of Clausius-Clapeyron equation was used for calculation of $\Delta H_{\text {st,a }}$ which were low at low surface coverage and increased progressively for untreated, $\mathrm{H}_{3} \mathrm{PO}_{4}$ - and $\mathrm{ZnCl}_{2}$-treated teff straw. For $\mathrm{NaOH}$-treated teff straw, $\Delta H_{\text {st,a }}$ was higher at low surface coverage which decreased with increase in adsorption. All the adsorbents showed heterogeneous surface characteristics.

Acknowledgments First author is thankful to the Ministry of Education, Government of Ethiopia, for providing financial sponsorship to do Ph.D. in India.

\section{References}

Agbor VB, Cicek N, Sparling R, Berlin A, Levin DB (2011) Biomass pretreatment: fundamentals toward application. Biotechnol Adv 29:675-685
Ali I (2010) The quest for active carbon adsorbent substitutes: inexpensive adsorbents for toxic metal ions removal from wastewater. Sep Purfi Rev 39:95-171

Ali I (2012) New generation adsorbents for water treatment. Chem Rev 112:5073-5091

Ali I, Aboul-Enein HY (2002) Speciation of arsenic and chromium metal ions by reversed phase high performance liquid chromatography. Chemosphere 48(3):275-278

Ali I, Aboul-Enein HY (2006) Instrumental methods in metal ions speciation: chromatography, capillary electrophoresis and electrochemistry. Taylor \& Francis Ltd, New York. ISBN 0-84933736-4

Ali I, Gupta VK (2006) Advances in water treatment by adsorption technology. Nat Lond 1:2661-2667

Anandkumar J, Mandal B (2009) Removal of Cr(VI) from aqueous solution using Bael fruit (Aegle marmelos correa) shell as an adsorbent. J Hazard Mater 168:633-640

Aravindhan R, Madhan B, Rao JR, Nair BU, Ramasami T (2004) Bioaccumulation of chromium from tannery wastewater: an approach for chrome recovery and reuse. Environ Sci Technol 38:300-306

Bansal M, Garg U, Singh D, Garg VK (2009) Removal of Cr(VI) from aqueous solutions using pre-consumer processing agricultural waste: a case study of rice husk. J Hazard Mater $162: 312-320$

Bezuayehu T, Endale T, Negussie M (2014) The Teff straw: a novel low-cost adsorbent for quantitative removal of $\mathrm{Cr}(\mathrm{VI})$ from contaminated aqueous samples. Desalin Water Treat 56:2925-2936

Blanes PS, Bordoni ME, González JC, García SI, Atria AM, Sala LF, Bellú SE (2016) Application of soy hull biomass in removal of $\mathrm{Cr}(\mathrm{VI})$ from contaminated waters. Kinetic, thermodynamic and continuous sorption studies. J Environ Chem Eng 4:516-526

Boyd GE, Adamson AW, Meyers LS (1947) The exchange adsorption of ions from aqueous solution by organic zeolites: II kinetics. J Am Chem Soc 69:2836-2848

Cao NJ, Xu Q, Chen LF (1995a) Xylan hydrolysis in zinc chloride solution. Appl Biochem Biotechnol 51(52):97-104

Cao NJ, Xu Q, Chen LF (1995b) Acid hydrolysis of cellulose in zinc chloride solution. Appl Biochem Biotechnol 51(52):21-28

Cheng G, Varanasi P, Li C, Liu H, Melnichenko YB, Simmons BA, Kent MS, Singh S (2011) Transition of cellulose crystalline structure and surface morphology of biomass as a function of ionic liquid pretreatment and its relation to enzymatic hydrolysis. Biomacromolecules 12:933-941

Dakiky M, Khamis M, Manassra A, Mereb M (2002) Selective adsorption of chromium(VI) in industrial wastewater using lowcost abundantly available adsorbents. Adv Environ Res 6:533-540 
Dhir B, Kumar R (2010) Adsorption of heavy metals by Salvinia biomass and agricultural residues. Int $\mathrm{J}$ Environ Res 4:427-432

Doan HD, Lohi A, Dang VBH, Dang-Vuc T (2008) Removal of $\mathrm{Zn}^{+2}$ and $\mathrm{Ni}^{+2}$ by adsorption in a fixed bed of wheat straw. Process Safety Environ Prot 86:259-267

Ebrahimi A, Ehteshami M, Dahrazma B (2015) Isotherm and kinetic studies for the biosorption of cadmium from aqueous solution by Alhaji maurorum seed. Process Saf Environ Prot 98:374-382

Elwakeel KZ (2010) Removal of $\mathrm{Cr}(\mathrm{VI})$ from alkaline aqueous solutions using chemically modified magnetic chitosan resins. Desalination 250:105-112

Garg SK, Tripathi M, Srinath T (2012) Strategies for chromium bioremediation of tannery effluent. In: Reviews of environmental contamination and toxicology, vol 217. Springer, US, pp 75-140

Gonzalez MH, Araújo GC, Pelizaro CB, Menezes EA, Lemos SG, de Sousa GB, Nogueira AR (2008) Coconut coir as biosorbent for $\mathrm{Cr}(\mathrm{VI})$ removal from laboratory wastewater. J Hazard Mater 159(2-3):252-256

Gurgel LVA, Melo JCP, Lena JC, Gil LF (2009) Adsorption of chromium(VI) ion from aqueous solution by succinylated mercerized cellulose functionalized with quaternary ammonium groups. Bioresour Technol 100(13):3214-3220

Ho YS (2004) Citation review of Lagergren kinetic rate equation on adsorption reactions. Scientometrics 59:171-177

Ho YS, McKay G (1998) A comparison of chemisorptions kinetic models applied to pollutant removal on various sorbents. Process Safety Environ Protect 76:332-340

Huang K, Xiu Y, Zhu H (2015) Removal of hexavalent chromium from aqueous solution by crosslinked mangosteen peel biosorbent. Int J Environ Sci Technol 12:2485-2492

Jeffries TW, Jin YS (2000) Ethanol and thermotolerance in the bioconversion of xylose by yeast. Adv Appl Microbiol 47:221-268

Kunquan L, Yuan J, Xiaohua W, Di B, Hua L, Zheng Z (2015) Effect of nitric acid modification on the lead(II) adsorption of mesoporous biochars with different mesopore size distributions. Clean Technol Environ Policy. doi:10.1007/s10098-015-1056-0

Langford JI, Wilson AJC (1978) Scherrer after sixty years: a survey and some new results in the determination of crystallite size. J Appl Cryst 11:102-113

Limayem A, Ricke SC (2012) Lignocellulosic biomass for bioethanol production: current perspectives, potential issues and future prospects. Prog Energy Combust Sci 38:449-467

Lopez-Linares JC, Cara C, Moya M, Ruiz E, Castro E, Romero I (2013) Fermentable sugar production from rape seed straw by dilute phosphoric acid pretreatment. Ind Crops Products 50:525-531

Mall ID, Srivastava VC, Agarwal NK (2006) Removal of orange-g and methyl violet dyes by adsorption onto bagasse fly ash-kinetic study and equilibrium isotherm analyses. Dyes Pigments 69:210-223

Martınez LJ, Munoz-Bonilla A, Mazario E, Recio FJ, Palomares FJ, Herrasti P (2015) Adsorption of chromium(VI) onto electrochemically obtained magnetite nanoparticles. Int J Environ Sci Technol 12:4017-4024

Mishra A, Jha B (2009) Isolation and characterization of extracellular polymeric substances from micro-algae Dunaliella salina under salt stress. Bioresour Technol 100(13):3382-3386

Mosier N, Wyman C, Dale B (2005) Features of promising technologies for pretreatment of lignocellulosic biomass. Bioresour Technol 96:673-686

Mulu BD (2013) Batch sorption experiments: Langmuir and Freundlich isotherm studies for the adsorption of textile metal ions onto teff straw (Eragrostis tef) agricultural waste. J Thermodyn. doi:10.1155/2013/375830

Ngah WS, Wan KM, Hanafiah MA (2008) Removal of heavy metal ions from wastewater by chemically modified plant wastes as adsorbents: a review. Bioresour Technol 99:3935-3948
Nurchi MV, Villaescusa I (2011) The chemistry behind the use of agricultural biomass as sorbent for toxic metal ions: $\mathrm{pH}$ influence, binding groups, and complexation equilibria. In: Matovic D (ed) Biomass - Detection, Production and Usage. In Tech, pp 409-424. ISBN: 978-953-307-492-4. http://www. intechopen.com/books/biomass-detection-production-and-usage/ the-chemistry-behind-the-use-of-agricultural-biomass-as-sorbentfor-toxic-metal-ions-ph-influence-bi. Accessed 11 Jan 2016

Park D, Yun Y, Park JM (2005) Studies on hexavalent chromium biosorption by chemically treated biomass of Ecklonia $s p$. Chemosphere 60:1356-1364

Park S, Baker JO, Himmel ME, Parilla PA, Johnson DK (2010) Cellulose crystallinity index: measurement techniques and their impact on interpreting cellulase performance. Biotech Biofuel 3:10

Rao RAK, Rehman F (2010) Adsorption studies on fruits of Gular (Ficus glomerata): removal of $\mathrm{Cr}(\mathrm{VI})$ from synthetic wastewater. J Hazard Mater 181:405-412

Raymon C (1998) Chemistry: thermodynamic, vol 737. McGraw-Hill, Boston

Santos FA, Alban L, Frankenberg CLC, Pires M (2016) Characterization and use of biosorbents prepared from forestry waste and their washed extracts to reduce/remove chromium. Int J Environ Sci Technol 13:327-338

Seyfu K (1997) Tef Eragrostis tef (Zucc) trotter promoting the conservation and use of underutilized and neglected crops 12 institute of plant genetics and crop plant research. Gatersleben/ International Plant Genetic Resources Institute, Rome

Sharma DC, Forster CF (1994) A preliminary examination into the adsorption of hexavalent chromium using low cost adsorbents. Bioresour Technol 47:257-264

Shiow-Tien S, Norasikin S, Khairiraihanna J, Hanapi M (2014) Surface chemistry modifications of rice husk toward enhancement of $\mathrm{Hg}(\mathrm{II})$ adsorption from aqueous solution. Clean Technol Environ Policy 16:1747-1755

Simkovic I, Antal M, Alfoldi J (1994) Fractionation of wheat straw meal after pretreatment with acidified zinc chloride solutions. Carbohydr Polym 23:111-114

Srivastava VC, Mall ID, Mishra IM (2007) Adsorption thermodynamics and isosteric heat of adsorption of toxic metal ions onto bagasse fly ash (BFA) and rice husk ash (RHA). Chem Eng J 132:267-278

Suzuki M, Fujii T (1982) Concentration dependence of surface diffusion coefficient of propionic acid in activated carbon particles. AIChE J 28:380-385

Taherdanak M, Zilouei H (2014) Improving biogas production from wheat plant using alkaline pretreatment. Fuel 115:714-719

Teixeira C, Tarley R, Zezzi M, Arruda A (2004) Biosorption of heavy metals using rice milling by-products. Characterisation and application for removal of metals from aqueous effluents. Chemosphere 54:987-995

Venkatesan G, Senthilnathan U, Shameela R (2014) Cadmium removal from aqueous solutions using hybrid eucalyptus wood based activated carbon: adsorption batch studies. Clean Technol Environ Policy 16:195-200

Vermeulen T (1953) Theory for irreversible and constant pattern solid diffusion. Ind Eng Chem 45(8):1664-1670

Wassie AB, Srivastava VC (2016) Teff straw characterization and utilization for chromium removal from wastewater: kinetics, isotherm and thermodynamic modeling. J Environ Chem Eng 4:1117-1125

World Health Organization (ed) (2008) Guidelines for drinking-water quality. World Health Organization, Geneva. ISBN 9241546743

$\mathrm{Xu}$ J, Cheng JJ, Sharma-Shivappa RR, Burns JC (2010) Lime pretreatment of switchgrass at mild temperatures for ethanol production. Bioresour Technol 101:2900-2903

Yang H, Yan R, Chen H, Ho Lee D, Zheng C (2007) Characteristics of hemicellulose, cellulose and lignin pyrolysis. Fuel 86:1781-1788 